\title{
PENINGKATAN PELAYANAN KTP-EKTRONIK MELALUI INOVASI JEMPUT BOLA PADA DINAS KEPENDUDUKAN DAN PENCATATAN SIPIL KABUPATEN SINJAI
}

\author{
The Improvement of KTP-Electronic Services Through Proactive Innovation in The Department of \\ Population and Civil Registration of Sinjai Regency
}

\author{
Fausiah Arma ${ }^{1}$, Husain Hamka ${ }^{2}$ Juharni $^{2}$ \\ ${ }^{1}$ Dinas Kependudukan dan Pencatatan Sipil Kabupaten Sinjai \\ ${ }^{2}$ Program Studi Ilmu Administrasi Negara Program Pascasarjana Universitas Bosowa \\ Email: fausiaharma5@gmail.com
}

Diterima: 15 Februari 2020

Dipublikasikan: 05 Juni 2020

\begin{abstract}
ABSTRAK
Penelitian ini mengidentifikasi implementasi dan faktor-faktor pelayanan pelayanan KTP-eL melalui Inovasi Jemput Bola Pada Dinas Kependudukan dan Pencatatan Sipil Kabupaten Sinjai. Penelititian ini merupakan penelitian kualitatif, dimana subyek penelitian adalah pegawai Dinas Kependudukan dan Pencatatan Sipil Kabupaten Sinjai. Sumber data terdiri dari data primer dan sekunder yang diperoleh dengan melakukan wawancara, observasi dan pengumpulan dokumen. Kemudian data dianalisa dengan metode kualitatif. Penelitian ini membahas peningkatan kualitas pelayanan dengan pendekatan beberapa indikator yaitu pengembangan kelembagaan organisasi, perubahan sikap dan karakter para pelaku birokrat, dan redesain proses pelaksanaan pelayanan. Implementasi inovasi pelayanan KTP-eL diukur melalui prosedur pelayanan, produk pelayanan, waktu penyelesaian, biaya belayanan, dan kompotensi petugas pemberi layanan. Sedangkan untuk mengidentifikasi faktor-faktor yang mempengaruhi peningkatan pelayanan, dilakukan beberapa pendekatan yaitu: sumber daya manusia, anggaran, dan pendukung sistem. Pengembangan kelembagaan organisasi telah berjalan dengan banyaknya berbagai inovasi sehingga dengan inovasi tersebut nampak kemampuan lembaga mengefektifkan penggunaan sumber daya manusia serta keuangan yang tersedia. Dalam pelaksanaan inovasi tersebut dilihat dari prosedur, produk, waktu dan biaya serta kompetensi petugas sudah ada warna baru dalam pelayan publik terkhusus pelayanan KTP-eL . Walaupun masih perlu ditingkatkan seperti peningkatan SDM dalam bentuk pelatihan-pelatihan, anggaran yang memadai serta memperhatikan sarana dan prasarana yang dipakai petugas lapangan dalam memberikan pelayanan langsung ke masyarakat.
\end{abstract}

Kata Kunci: Pelayanan, Inovasi, Publik, KTP-eL, Sinjai

\begin{abstract}
This research identifies the implementation and service factors of KTP-eL through proactive innovation at the Department of Population and Civil Registration Office of Sinjai Regency. This research is a qualitative research, where the research subjects are employees of the Department of Population and Civil Registration in Sinjai Regency. Data sources consist of primary and secondary data obtained by conducting interviews, observations and collecting documents. Then the data is analyzed by using qualitative methods. This study will discuss the improvement of service quality using a number of indicators, which are the development of organizational institutions, changes in attitudes and character of bureaucrats, and redesigning the process of service delivery. The implementation of KTP-eL service innovation is measured by several indicators, namely service procedures, service products, completion time, service costs, and the potential of service providers. Meanwhile, to identify the factors that influence service improvement, several approaches are used, namely: human resources, budget, and supporting systems. The institutional development of the organization has been running with a lot of various innovations so that with these innovations the institutional ability appears to be effective in the use of available human and financial resources. In implementing the innovation based on the procedures, products, time and cost, and competence of officers, there is a new color in the public service, especially KTP-eL service at the Department of Population and Civil Registration Sinjai Regency. However, it still needs to be improved, such as increasing human resources through trainings, allocating adequate budget and paying attention to the facilities and infrastructures used by field officers in providing direct services to the community.
\end{abstract}

Keywords: Service, Innovation, Public, KTP-eL, Sinjai

\section{PENDAHULUAN}

Peningkatan serta tuntutan yang masyarakat inginkan pada pelayanan publik (public service) yang efektif dan efesien serta memuaskan dari para pegawai pemerintahan sebagai pelayan publik semakin populer. Hal ini terjadi karena perkembangan kebutuhan, keinginan serta harapan para masyarakat yang selalu terus bertambah, yang masyarakat sebagai subyek dari layanan merasakan pelayanan yang masih berbelit-belit dan beresiko karena rantai birokrat yang begitu panjang.

Untuk mewujudkan pelayanan publik yang baik maka pemerintah menempatkan jumlah dan kualitas staf/aparat yang ada harus sesuai dan memiliki pemahaman akan pelayanan publik yang baik sehingga pelayanan publik dapat tepat sasaran dan pelayanan yang diberikan juga dapat mendekatkan birokrasi dengan 
masyarakat (Dwiyanto, 2008). Undang-undang Nomor 25 Tahun 2009 tentang Pelayanan Publik memaparkan bahwa ruang lingkup pelayanan publik dapat digolongkan ke dalam dua bentuk, yaitu pelayanan barang dan jasa publik dan pelayanan administrastif. Sehubungan dengan itu prinsip-prinsip peayanan publik itu di lihat dengan adanya kepastian hukum, keterbukaan, partisipatif, akuntabilitas, kepentingan umum, profesionalisme, kesamaan hak dan keseimbangan hak dan kewajiban.

Untuk mendukung pendataan penduduk tersebut, Undang Undang Administrasi Kependudukan dan direvisi terakhir menjadi Undang Undang Nomor 24 Tahun 2013 tentang Perubahan Atas Undang Undang Nomor 23 Tahun 2006 tentang Administrasi Kependudukan. Dalam UU Nomor 24 Tahun 2013 tentang Administrasi Kependudukan, data dikelompokkan, pertama Data Pribadi adalah data perseorangan tertentu yang disimpan, dirawat, dan dijaga kebenaran serta dilindungi kerahasiaannya (pasal 1 point 22). Kedua Database adalah kumpulan berbagai jenis data kependudukan yang tersimpan secara sistematik, terstruktur dan saling berhubungan dengan menggunakan perangkat lunak, perangkat keras dan jaringan komunikasi data (pasal 1 point 29 PP No. 37 Tahun 2007). Serta ketiga Data Kependudukan adalah data perseorangan atau data agregat yang terstruktur sebagai hasil kegiatan pendaftaran penduduk dan pencatatan sipil.

Masalah yang umum terjadi dengan melihat masih ada masyarakatnya belum memiliki KTP. Dengan berbagai alasan dalam pembuatan KTP masih rumit dan berbelit dari satu meja ke meja yang lain. Selain dari itu, masalah yang sering di jumpai di masyarakat waktu pengurusan KTP itu memerlukan waktu yang lama karena birokrasi yang harus dilewati terlalu banyak, mulai dari surat pengantar dari desa, diketahui oleh Kecamatan, sesudah itu baru ke Dinas Kependudukan dan Catatan Sipil untuk mengurusnya (Achyar et al., 2019). Sehingga mengurunkan niat masyarakat untuk memiliki KTP. Kebanyakan masyarakat baru mengurus KTP ketika kedua hal tersebut mau dipergunakan. Seperti syarat pernikahan, syarat administrasi pengurusan sertifikat tanah, syarat penerima bantuan dan lain sebagainya (Wijaya, 2017).

Terkhusus di Kabupaten Sinjai masalah yang sering di jumpai dalam pengurusan KTP-eL itupun tidak terlepas dari masalah umum diatas, prosedur yang berbelit serta birokrasi yang panjang serta proses pelayanan KTPeL dengan efesiensi waktu yang tidak jelas, terkadang masyarakat harus menggunakan waktu satu sampai dua hari dalam pengurusan KTP-eL di Dinas Kependudukan dan Catatan Sipil Kabupaten Sinjai. Sehingga masyarakat yang berdomisili yang jauh memerlukan biaya operasional yang banyak dalam pengurusan dokumen kependudukan tersebut (Nurvadillah, 2018; Holidi, A. 2015).

Inovasi yang dilakukan Dinas Kependudukan dan pencatatan Sipil Kabupaten Sinjai dalam pelayanan publik memberikan warna yang cerah terhadap pelayanaan kependudukan di Indonesia terkhusus di Kabupaten Sinjai. Kegiatan inovasi tersebut fokus pada empat agenda kegiatan dalam pelayanan publik yaitu pertama pelayanan KTP-eL pemula sasarannya adalah siswa SMA/MA/sederajat yang sudah wajib memiliki KTP. Kedua, Penduduk rentan dan layanan kesehatan. Ketiga, penyandang disabilitas, cacat fisik/mental dan lansia. dan keempat, adalah perbaikan KTP kepada masyarakat yang memiliki dua identitas atau KTP ganda. Dengan sasaran tersebut Dinas Kependudukan dan Catatan Sipil Kabupaten Sinjai langsung terjun kelapangan menyambangi warga dan sekolah-sekolah sehingga terciptanya pelayanan yang mudah (Imbalo, 2006).

Penelitian ini bertujuan untuk menganalisis implementasi dan faktor-faktor pelayanan pelayanan KTP-eL melalui inovasi jemput bola pada Dinas Kependudukan dan Pencatatan Sipil Kabupaten Sinjai.

\section{METODE PENELITIAN}

Penelitian ini menggunakan metode penelitian kualitatif dengan tipe deskriptif dengan dasar penelitian studi. Metode seperti ini lebih dipilih karena penelitian ini lebih mengutamakan analisa deskriptif. Penelitian kulaitatif digunakan dengan maksud untuk memahami fenomena tentang apa yang dialami oleh subyek penelitian secara holistic, dan dengan cara deskripsi dalam bentuk kata-kata dan bahasa pada suatu konteks khusus yang alamiah dan dengan memanfaatkan berbagai metode ilmiah, Moleong (2010).

\section{HASIL DAN PEMBAHASAN}

Istilah pelayanan dalam bahasa Inggris "sevice" A.S. Moenir (2002) mendefinisikan pelayanan sebagai kegiatan yang dilakukan oleh seseorang atau sekolompok orang dengan landasan tertentu dimana tingkat pemuasannya hanya dapat dirasakan oleh orang yang melayani atau dilayani, tergantung kepada kemampuan penyedia jasa dalam memenuhi harapan pengguna. Menurut Sedarmayanti (2009), pelayanan publik merupakan pelayanan yang ditujukan terhadap kebutuhan yang bersifat umum dari masyarakat, karena itu dapat dituntut agar dilaksanakan. Sedangkan Wasistiono dalam Hardiyansyah (2011) menyatakan bahwa pelayanan umum atau pelayanan publik adalah pemberian jasa baik oleh pemerintah, pihak swasta atas nama pemerintah ataupun pihak swasta kepada masyarakat, dengan atau tanpa pembayaran guna memenuhi kebutuhan dan atau kepentingan masyarakat.

\section{Peningkatan Kualitas Pelayanan}

Peningkatan kualitas pelayanan dalam penelitian diukur beberapa indikator yakni pengembangan kelembagaan organisasi, perubahan sikap dan karakter para pelaku birokrat, meredesain proses pelaksanaan pelayanan, sederhanakan birokrasi, mengutamakan kepentingan masyarakat, pemanfaatan dan pemberdayaan bawahan. 
Pengembangan kelembagaan sama halnya dengan pembinaan kelembagaan yaitu suatu prose untuk memperbaiki kemampuan lembaga guna mengefektifkan penggunaan suumber daya manusia dengan keuangan yang tersedia. Proses ini dapat dilakukan secara internal oleh kepala Dinas Kependudukan dan Pencatatan Sipil Kabupaten Sinjai. Pengembangan Dinas Kependudukan dan Pencatatan Sipil Kabupaten Sinjai, dapat menyangkut system manajemen, pemantauan dan evaluasi dari setiap pekerjaan berdasar tupoksi masing-masing.

Pengembangan kelembagaan dengan penataan organisasi dan fungsi-fungsi kearah yang lebih baik. Yang sesungguhnya amat penting. Serta pengembangan pada sisi nilai-nilai yang membentuk manusia-manusia birokrat. Internalisasi nilai-nilai merupakan kunci terhadap peningkatan kinerja bawahan. Yang perlu menjadi perhatian adalah memperbaiki sikap birokrasi dalam hubungan dengan masyarakatnya, yaitu birokrasi harus membangun partisipasi rakyat, birokrasi hendaknya tidak berorientasi kuat tapi harus lebih kepada yang kurang berdaya, birokrasi harus bergeser dari mengendalikan menjadi mengarahkan dan memberdayakan.

Dinas Kependudukan dan Pencatatan Sipil Kabupaten Sinjai perlu memperhatikan dan meningkatkan penyelenggaraan pelayanan, karena ada kewajiban organisasi khususnya Dinas Kependudukan dan Pencatatan Sipil Kabupaten Sinjai yang harus dilakukan serta pemenuhan hak penerima layanan yaitu masyarakat yang harus diperhatikan. Ini semua memaksa manajemen lembaga yang ada di Dinas tersebut untuk melihat kembali sejauh mana kualitas yang dapat diberikan kepada masyarakat dalam pelayanan KTP-eL tersebut.

Perhatian organisasi dalam kualitas dalam hal ini Dinas Kependudukan dan Pencatatan Sipil Kabupaten Sinjai meliputi berbagai aspek. Diantaranya adalah dilihat dari bagaimana membangun budaya peningkatan kualitas, memberikan kesadaran kepada sumber daya manusia organisasi akan pentingnya kualitas pelayanan. Disamping itu juga perlu perhatian terhadap aspek manajemen dalam mengaplikasikan proses penyelenggaraan pelayanan organisasi. Tidak kalah pentingnya adalah penentuan standard yang baku tentang kualitas pelayanan setiap program sebagai pedoman dalam penilaian kinerja (Ratminto \& Atik, 2010).

Selain dari itu, dalam peningkatan kualitas pelayanan, Disadari sepenuhnya bahwa manfaat dari suatu program kerja merupakan indikator utama yang perlu diperhatikan dalam penyusunan suatu program kerja. Program kerja yang baik, akan memberikan manfaat yang sebesar-besarnya bagi kemajuan organisasi dan masyarakat dalam mengembang suatu visi organisasi. Semakin baik manfaatnya suatu program kerja, maka semakin baik program kerja tersebut, manfaat yang dimaksud adalah untuk jangka pendek dan jangka panjang. Hal ini sejalan dengan pendapat Aprilia (2014) bahwa manfaat dari suatu kegiatan seharusnya menjadi dasar utama dalam pembuatan suatu program kerja bagi
Dinas ataupun lembaga-lembaga pemerintah, terutama yang memberikan maanfaat sebesar-besarnya bagi masyarakat atau peningkatan kualitas pelayanan kepada masyarakat. Hal ini disebabkan karena tupokosi utama pemerintah adalah pelayan bagi masyarakat.

Manfaat suatu program kerja, dapat juga dinikmati oleh pegawai dari dinas itu sendiri. Hal ini biasanya dilakukan dalam rangka peningkatan kapasitas atau kualitas pekerja itu sendiri dalam memberikan pelayanan kepada masyarakat. Sehubungan dengan hal tersebut, maka Dinas Kependudukan dan Pencatatan Sipil Kabupaten Sinjai membuat program kerja berupa pelatihan peningkatan sumber daya manusia pegawai yang ada. Dengan semakin tingginya kualitas SDM yang ada, maka dapat mendukung terwujdunya tertib administrasi yang lebih baik. Pelatihan ini biasa dilakukan di ibukota kabupaten, ibukota propinsi bahkan di luar propinsi juga kadang diikuti. Pelatihan yang merupakan suatu alat atau sarana dalam rangka peningkatan kualitas sumber daya manusia, khususnya dalam upaya menciptakan tenaga-tenaga aparatur yang semakin kompeten.

Tidak sedikit program kerja Dinas Kependudukan dan Pencatatan Sipil Kabupaten Sinjai mendapatkan tanaggapan positif dari masyarakat. Di antaranya adalah program yang terkait dengan KTP. Kegiatan ini menunjukkan adanya upaya pemerintah Kabupaten Sinjai dalam mewujudkan percepatan semua penduduk mendapatkan Kartu Tanda Penduduk. Hal ini terbukti bagus karena mampu meningkatkan jumlah kepemilikan dokumen kependudukan, khususnya bagi yang wajib KTP. Terpenuhinya bagi masyarakat yang mendapat pelayanan langsung dokumen kependudukan tingkat Desa dan Kelurahan.

Program pembuatan KTP-eL dan pembuatan akta kelahiran merupakan salah satu program kerja Dinas Kependudukan dan Pencatatan Sipil Kabupaten Sinjai, mendapatkan tanggapan cukup besar bagi masyarakat dan stakeholder lainnya Keberadaan kedua kegiatan ini memudahkan masyarakat dalam pengurusan-pengurusan surat-surat lainnya.

Salah satu hal yang mendapatkan perhatian dalam evaluasi program kerja di Dinas Kependudukan dan catatan Sipil Kabupaten Sinjai adalah penggunaan anggaran. Nampaknya, pegawai yang bertugas berupaya semaksimal mungkin untuk menggunakan dana lebih efektif dan lebih efisien dengan tetap memperhatikan semua aspek penggunaan keuangan negara. Dengan konsep seperti ini, maka pihak pegawai dapat bekerja dengan lebih tenang dan dapat memberkan hasil yang lebih baik dan lebih maksimal.

Dinas Kependudukan dan Pencatatan Sipil, setiap tahunnya membuat program kerja yang dibuat sedemikian rupa sehingga mampu memberi manfaat bagi masyarakat. Besar kecenderungan bahwa, dampak dari program kerja tersebut dari tahun ketahun semakin baik dan semakin dirasakan oleh masyarakat. Setiap tahunya program kerja yang dibuat terlebih dahulu disetujui oleh Dewan 
perwakilan Rakyat serta disesuaikan dengan besarnya anggaran atau dana pemerintah yang tersedia. Kesemuanya ini dilakukan, karena Dinas ini menyadari sepenuhya akan tupoksi yang diembang dalam rangka mewujdukan visi dan misi Kabupaten Sinjai dalam rangka mempercepat kesejahteraan masyarakat.

Tjiptono (2012), menyatakan untuk memperbaiki kulaitas pelayanan public terhadap beberapa prinsip yang perlu diperhatikan guna membentuk dan mempertahankan lingkungan yang tepat dalam melaksanakan penyempurnaan kualitas secara berkesinambungan dengan dukungan aparat dan masyarakat, yaitu: Kepemimpinan, Pendidikan, Perencanaan, Review, Komunikasi, dan Penghargaan dan pengakuan.

\section{Implementasi Inovasi Pelayanan KTP-eL ektrinik}

Dalam implementasi inovasi pelayanan KTP-eL Dinas Kependudukan dan Catatan Sipil Kabupaten Sinjai diukur dengan beberapa indikator, yaitu Prosedur Pelayanan, Produk Pelayanan, Waktu Penyelesaian, Biaya Pelayanan, dan Kompotensi petugas pemberi layanan.

Dalam pelaksanaan standar pelayanan publik menjadi sebuah acuan bagi para pelaksana pelayanan public sebagai standar dalam melaksanakan pelayanan. Selain itu standar pelayanan yang telah disusun dan ditetapkan oleh unit pelayanan public harus dipublikasikan kepada masyarakat, baik melalui media cetak maupun media elektronik sehingga semua masyarakat yang ingin mendapatkan pelayanan KTP-eL sehingga masyarakat mempunyai gambaran jelas mengenai bagaimana keadaan pelayanan Dinas Kependudukan dan Pencatatan Sipil Kabupaten Sinjai, tentang mekanisme, prosedur, waktu pelayanan, biaya dan berbagai hal lainnya yang disediakan oleh Dinas Kependudukan dan Pencatatan Sipil Kabuapten Sinjai, masyarakat bias mengetahui baik buruknya pelayanan yang diberikan, dan apabila pelayanan tidak sesuai standar pelayanan yang dipublikasikan, masyarakat berhak untuk protes atau melaporkan unit pelayanan publik yang bersangkutan, baik kepada unit pengawasan maupun melalui layanan pengaduan yang disediakan oleh Dinas Kepndudukan dan Pencatatan Sipil Kabupaten Sinjai.

Faktor yang kadang bermasalah dalam pelaksanaan suatu program kerja adalah waktu, dimana waktu yang direncanakan tidak sesuai dengan rencana yang telah diprogramkan. Perubahan ini terjadi karena keterbatasan dana yang biasanya agak lambat baru cair, ataukah ada kegiatan mendadak dari atasan yang memaksa kegiatan yang sudah direncanakan terpaksa ditunda pelaksanaannya. Kenyataan ini sejalan dengan pendapat Rivai (2010) bahwa mengevaluasi kinerja dinas atau instnasi pemerintah memerlukan pertimbangan dan strategi tertentu, yang berbeda dengan melakukan evaluasi pada Lembaga swasta. Evaluasi kinerja instansi pemerintah kadang dihadapkan pada persoalan yang berbelit-belit, diantaranya faktor koordinasi antara lembaga yang berbeleit-belit, perubahan jadwal kerja yang kerja, karena adanya arahan atau petunjuk dari atasan dan atau keterlambatan program berjalan disebabkan oleh katerlambatan dana dan petunjuk teknis dari pusat.

Upaya-upaya peningkatan kinerja pegawai senantiasa dilaksanakan, salah satu di antaranya adalah melakukan evaluasi terhadap proses program kerja pada suatu Dinas atau instanasi. Sekaitan dengan proses pelaksanaan program kerja pada Dinas Kependudukan dan Pencatatan Sipil Kabupaten Sinjai, maka disarankan beberapa hal guna peningkatan hasil program kerja yang telah ditetapkan. Di antarnya adalah (a) penambahan sarana dan prasarana pendukung, baik dalam bentuk peremajaan sarana/prasarana yang ada maupun dengan mendatangkan peralatan baru yang lebih baik dan sesuai dengan teknologi terkini, (b) peningkatan SDM pegawai sendiri, melalui latihan dan seminar tertentu, apalagi pada saat ini, kemajuan ilmu dan teknologi membuat setiap pegawai seharunya lebih meningkatkan kualitasnya sehingga bekerja dengan teknologi terkini serta (c) kegiatan yang dipandang baik dan memberikan manfaat kiranya dilanjutkan dimasa yang akan datang, hal ini karena memang ada program yang tidak bisa selesai dengan hanya satu tahun anggaran, tetapi membutuhkan beberapa tahun baru selesai. Pada dasarnya evaluasi tentang program kerja yang baik perlu dilanjutkan dan lebih disempurnakan, dengan tetap mengacu pada hasilhasl program kerja sebelumnya serta kebutuhan dan tantangan kemajuan ilmu dan teknologi yang berkembang dengan sangat pesat pada dewasa ini.

Zauhar (2005), menyatakan kualitas pelayanan ada penyesuaian terhadap perincian-perincian (conformance to specification) dimana kualitas ini dipandang sebagai derajat unggulan yang ingin dicapai, dilakukan control terus menerus dalam mencapai keunggulan tersebut dalam rangka memenuhi kebutuhan pengguna jasa.

Sehubungan dengan pendapat tersebut diatas, dalam implementasi pelayanan diperlukan atau memperhatikan kualitas pelayanan. Menurut Supriyono (2003), pelayanan publik yang berkualitas memiliki beberapa kriteria dan indicator sebagai berikut: Tepat dan Relevan, tersedia dan terjangkau, dapat menjamin rasa keadilan, dapat diterima, ekonomis dan efesien dan efektif.

\section{Faktor-faktor yang mempengaruhi peningkatan pelayanan}

Identifikasi faktor-faktor yang mempengaruhi peningkatan pelayanan, dilakukan beberapa pendekatan yaitu : Sumber Daya Manusia, Anggaran, dan Pendukung system. Masukan yang pertama diperhatikan adalah sumber daya manusia. Nampakanya, pegawai yang ada di Dinas Kependudukan dan Pencatatan Sipil Kabupaten Sinjai telah banyak belajar dan bekerja untuk kepentingan dan keberhasilan Dinas ini sendiri. Keberadaan SDM sangat menentukan kesuksesan suatu program kerja. Hal ini sejalan dengan pendapat Darminto (2013) menyatakan bahwa salah satu aspek input dalam suatu program kerja adalah sumber daya manusia yang berkualitas. Jika SDM 
yang mengelola proses tersebut baik, maka besar kemungkinan program yang dilaksanakan dapat memberikan hasil sebagaiamana yang diharapkan bersama.

Karakteristik organisasi Dinas Kependudukan dan Catatan Sipil Kabupaten Sinjai, ada suatu instansi pemerintah yang mengurusi bidang kependudukan. Suatu instansi pemerintah, hampir semua kegiatannya dibiayai oleh negara, olehnya itu kegiatan atau program-program yang dibuat semuanya didasarkan atas dana yang disiapkan pemerintah sendiri. Input terkait dengan dana, nampanya cukup baik walaupun dana yang dianggarkan masih relative minim, karena nyatanya progrram-program yang ada di Dinas ini masih tetap berjalan setiap tahunnya.

Nampak bahwa proses pendanaan merupakan hal yang melandasi kegiatan atau program kerja Dinas Kependudukan dan Pencatatan Sipil, dimana proses penentuan besar dana yang digunakan didasarkan atas kemampuan daerah serta dana-dana dari pusat. Di samping itu, dana yang digunakan harus disesuaikan dengan persetujuan Dewan perwakilan Rakyat setempat. Sejalan dengan hal tersebut, Burhanuddin (2014) menyatakan bahwa dalam suatu kegiatan atau program kerja instansi pemerintah, aspek pendanaan dan sumber daya manusia harus menjadi pertimbangan utama, bahkan dana dalam suatu kegiatan kadang diedentikkan darah bagi tubuh.

Hal-hal yang diperhatikan oleh Dinas kependudukan dan Catatan Sipil Kabupaten Sinjai dalam membuat program kerja di antaranya adalah (a) keberlanjutan program kerja tahun sebelumnya, yang berarti ada upaya menciptakan kegiatan-kegiatan yang baik dilaksanakan lagi pada tahun program berjalan (b) kemampuan dana yang tersedia, artinya pengaturan penggunaan dana harus diberikan skala prioritas (c) sumber daya manusia yang melaksanakanannya, artinya pegawai yang ada harus diperhatikan kemampuannya, jangan sampai ada program yang dibaut tapi ternyata tidak mampu dilaksnakan (d) ketersediaan sarana dan prasarana, dalam hal ini kegiatan bukan hanya dilakukan di kantor, tetapi kadang dlakukan didaerah-daerah, sehingga kesiapan sarana harus diperhatikan dan (e) kebijakan yang harus dikembangkan, atas anjuran pejabat di atas atau kegiatan yang harus dilaksanakan karena perkembangan ilmu dan teknologi yang semakin maju.

Kendala yang dihadapi dalam penbuatan program kerja pada Dinas Kependudukan dan Pencatatan Sipil Kabupaten Sinjai cukup banyak, namun demikian, pegawai yang ada berupaya maksimal menggunakan segala kemampuan yang ada agar program kerja tetap berjalan sebagimana mestinya. Kendala yang dihadapi di antaranya adalah (a) kemampuan pendanaan, dimana faktor ini sangat terasa bagi pegawai. Cukup banyak program kerja yang dibutuhkan masyarakat yang seharusnya dijadikan program kerja, namun tidak mampu dilaksanakan karena keterbatasan dana, (b) Keterbatasan sarana dan prasarana, hal ini disebabkan karena secara kuantitas maupun kualitas, sarana dan prasarana yang ada sudah seharusnya diperbaharui dengan yang lebih baik. Serta (c) keterbatasan sumber daya mananusia yang lebih profesional, hal ini sangat terasa terutama dalam penggunaan teknologi terkini atau barang-barang yang berteknologi tinggi, sebagai pegawai masih kewalahan menggunakannya.

Faktor yang perlu diperhatikan dalam evaluasi proses adalah ketersediaan sarana dan prasarana yang berfungsi sebagaimana yang diharapkan. Kondisi sarana/prasarana yang ada di kantor Dinas Kependudukan dan Pencatatan Sipil Kabupaten Sinjai masih masih minim. Dieperlukan pengecekan berkala sarana dan prasarana yang di pakai untuk pelayanan inovasi tersebut. Agar ada antisipasi sebelumnya ketika ada masalah dilapangan sewaktu pelayanan. Sehubungan dengan itu diperlukan sarana prasarana tambahan seperti alat rekaman sidik jari, alat rekaman iris mata serta fasilitas lainnya yang berhubungan dengan inovasi tersebut.

Sehubungan dengan sarana dan prasarana, Sujatmiko (2010) menyatakan bahwa sarana dan prasarana merupakan faktor yang perlu diperhatikan dalam rangka suksesnya suatu kegiatan atau program kerja. Jika sarana yang dibutuhkan tersedia dengan baik dan layak, maka kemunkinan besar pekerjaan atau kegiatan dapat berhasil pula dilaksanakan. Olehnya itu, sebaiknya setiap kegiatan yang akan dilaksanakan, sebaiknya disesuaikan dengan ketersediaan sarana dan prasarana yang tersedia.

Pada dasarnya, program kerja yang dibuat dan dilaksanakan dari tahun ke tahun telah memberikan hasil dan luaran yang cukup baik.Luaran dari kegiatan ini berupa laporan-laporan kegiatan, buku-buku kependudukan, dan lain sebagainya masih dapat dilihat dan dibaca pada kantor Dinas kependudukan dan Catatan Sipil Kabupaten Sinjai. Bahkan, tidak sedikit luaran dari Dinas ini yang menjadi referensi bagi dinas lainnya, khususnya yang terkait dengan kependudukan.

Salah satu luaran program yang dirasakan langsung oleh masyarakat adalah teresedianya blangko KTP-eL untuk pelayanan langsung di setiap desa/kelurahan dengan baik. Ketersediaan KTP-eL ini merupakan suatu perangkat kependudukan yang sangat dibutuhkan masyarakat, terutama kaitannya dengan pengurusan suratsurat lainnya.

Dalam menjalankan aktifitasnya, koordinasi dengan Dinas-Dinas terkait serta koordinasi yang baik dengan pemerintah kecamatan, kelurahan dan Desa yang cukup intens dilakukan. Koordinasi ini sangat dibutuhkan dan saling melengkapi dengan lembaga lainnya. Dengan koordinasi yang baik, memungkinkan luaran-luaran dari Dinas Kependudukan dan Catatan Sipil kabupaten Sinjai di masa yang akan datang semakin baik dan lebih mudah diterima masyarakat.

Luaran dari suatu kegiatan merupakan salah satu tolok ukur kesuksesan program itu sendiri. Menurut Budiman (2012) menyatakan bahwa program kerja pada suatu Dinas atau Lembaga perlu memperhatikan input, 
proses, luaran dan dampak, dalam hal ini luaran dan dampak perlu mendapatkan perhatian yang lebih serius karena berhubungan dengan hal-hal setelah kegiatan itu dilaksanakan. Luaran dan dampak akan menjadi indikator kesuksesan program itu sendiri.

Luaran dari Program kerja Dinas Kependdukan dan Pencatatan Sipil Kabupaten Sinjai merupakan salah satu bahan utama dalam menciptakan kesejahteraan bagi masyarakat Sinjai. Hal ini sesuai dengan tugas utamanya yakni suatu rangkaian kegiatan penataan dan penerbitan dokumen dan data kependudukan melalui pendaftaran penduduk, pencatatan sipil, dan pengelolaan informasi administrasi kependudukan serta pendayagunaan hasilnya. Sehubungan dengan hal ini Sutrisno (2013) menyatakan bahwa data kependudukan merupakan salah satu data yang dibutuhkan oleh pihak luar sebelum melakukan kerjasama dengan suatu daerah atau wilayah. Bahkan, jika suatu daerah berminat mendatangkan investor guna turut membangun daerahnya, maka pihak investor akan banyak bertanya tentang jumlah penduduk, jenis pekerjaan penduduk, struktur penduduk dan lain sebagainya, yang terkait dengan kependudukan.

Dalam rangka menciptakan luaran-luaran program kerja Dinas Kependudukan dan Pencatatan Sipil Kabaupaten Sinjai semakin baik dimasa yang akan datang, maka beberapa hal yang bagus dijadikan rekomendasi di antaranya adalah (a) program kerja yang baik pada tahun sebelumnya perlu dilanjutkan dan lebih disempurnakan, (b) program-program kerja yang luarannya terkait langsung dengan masyarakat perlu lebih ditingkatkan, karena topoksi lembaga pemerintah / dinas adalah melayani masyarakat, (c) perlu peningkatan kuantitas dan kualitas sarana dan prasarana yang ada sehingga dapat menciptakan luaran yang lebih baik dan lebih sempurna.

\section{KESIMPULAN}

Hasil penelitian dan pembahasan dapat disimpulkan bahwa pengembangan kelembagaan organisasi telah berjalan dengan banyaknya berbagai inovasi sehingga dengan inovasi tersebut nampak kemampuan lembaga mengefektifkan penggunaan sumber daya manusia serta keuangan yang tersedia. Dalam pelaksanaan inovasi tersebut dilihat dari prosedur, produk, waktu dan biaya serta kompetensi petugas sudah ada warna baru dalam pelayan publik terkhusus pelayanan KTP-eL . Walaupun masih perlu ditingkatkan seperti peningkatan SDM dalam bentuk pelatihan-pelatihan, anggaran yang memadai serta memperhatikan sarana dan prasarana yang dipakai petugas lapangan dalam memberikan pelayanan langsung ke masyarakat.

\section{DAFTAR PUSTAKA}

Aprilia. 2014. Pengertian Pelayanan Prima dan DasarDasar Pelayanan Prima, Universitas Airlangga, Surabaya.
Achyar, I. F., Juharni, J., \& Nurkaidah, N. 2019. Kualitas Pelayanan Dalam Sistem Penerbitan E-Ktp Pada Dinas Kependudukan Dan Pencatatan Sipil Kabupaten Maros. Jurnal Paradigma Administrasi Negara, 1(1), 27-31

Catherine Marshall and Gretchen B. Rossman, 1999 "Designing Qualitative Research 3e".California: Sage Publication Inc

Dwiyanto, Agus, 2008. Mewujudkan Good Governance Melalui PeLayan Publik. Yogyakarta. Gadjah Mada University Press.

Evans dan Lindsay, 1997. Manajemen Pelayanan Yang Berkualitas, Bandung, Armico.

Hardiyansyah. 2011. Kualitas Pelayanan Publik: Konsep, Dimensi, Indikator dan Implementasinya. Yogyakarta. Gava Media

Holidi, A. 2015. Pelayanan KTP Elektronik di Dinas Kependudukan dan Pencatatan Sipil Kabupaten Tanjung Barat. Tesis. Universitas Terbuka.

Keban, Yeremias T, 2008. Enam Dimensi Strategis Admnistrasi Publik: Konsep, Teori dan Isu. Yogyakarta. Gava Media.

Thoha, Miftah.2010. Kepemimpinan Dalam Manajemen. Jakarta: PT. Raja Grafindo Persada

Moleong, lexy J. 2010. Metodologi penelitian kulaitatif. Cetakan kedua puluh deLapan. Bandung: PT remaja Rosdakarya

Moenir, H. A. S., 2002. Manajemen Pelayanan Umum di Indonesia, Jakarta: Bumi Aksara.

Wijaya, Muamar Multi. 2017. Kualitas Pelayanan E KTP Di Keamatan Rajabasa. Skripsi, Universitas Lampung

Nurvadillah, 2018. Pengaruh Kualitas Pelayanan Terhadap Kepuasan Pemohon KTP-eL pada Dinas Kependudukan dan Pencatatan Sipil Kabuten Luwu, Jurnal edisi 6. Diakses 1 Spetember 2019

Imbalo, Pohan S. 2006. Jaminan Mutu Layanan Kesehatan: Dasar-dasar Pengertian dan Penerapan. Jakarta: EGC

Ratminto \& Atik, SW. 2010. Manajemen Pelayanan: Pengembangan ModeL Konseptual, Penerapan Citisen's Charter dan Standar Pelayanan Minimal. Yogyakarta. Pustaka PeLajar.

Rivai, Vethzal. 2010. Manajemen Sumber Daya Manusia untuk Perusahaan dari Teori Ke Praktik, Jakarta: PT. Raja Grafindo.

Sedarmayanti. 2004. Good Governance (Kepemerintahan Yang Baik) Bagian Kedua: membangus Sistem Manajemen Kinerja Guna Meningkatkan Produktivitas Menuju Good Governance (Kepemerintahan Yang Baik). Bandung. Mandar Maju.

Sedarmayanti. 2009. Reformasi Administrasi Publik, Reformasi Birokrasi, Dan Kepemimpinan Masa Depan. Bandung: PT. Refika Aditama

Surjadi. 2009. Pengembangan Kinerja Pelayanan Publik. Bandung. Refika Aditama PT. 
Supriyono, Maryanto. 2011. Buku pintar Perbankan, Yogyakarta. Andi

Tjiptono. 2002. Manajemen Jasa, Jakarta: Rajawali.

Tjiptono, Fandy. 2004. Manajemen Jasa. Yogyakarta: Andi Offset

Tjiptono, Fandy. 2012. Strategi Pemasaran. Yogyakarta: Andi.

Winarno, B. 2002. Teori dan Proses Kebijakan Publik, Yogyakarta: Media Pressindo.

Zauhar, Soesilo. 2005. Birokrasi, Birokratisasi dan Post Bureaucrasy. Malang: Unibraw. 